\title{
LIABILITY IN SPACE LAW: QUESTIONS ON PRACTICAL APPLICATION OF ABSOLUTE AND FAULT LIABILITY
}

\author{
by Sewela Masie \& Kaitlin Morris*
}

\section{Introduction}

With modern advances in technology, mankind is now faced with new legal problems and situations previously unanticipated. Space law in particular is relevant as, while most of the documents were drafted and assented to in the mid 1990's, there have since been great advances in space exploration and technology. This means that potential situations exist which are not expressly provided for in International Space Law. Therefore, since the answers for hypothetical questions cannot always be found explicitly in space law, we will be relying on the sources of international law listed in article $38(1)$ of the International Court of Justice Statutes, namely international conventions, international custom, general principles of law and judicial decisions and teachings. ${ }^{1}$ The rules of the Vienna Convention regarding the interpretation of Treaties must also be kept in mind, including that a state is obliged to refrain from acts that would defeat the object and purpose of a treaty that it has ratified. ${ }^{2}$

In practice the has not been any cases dealing with liability in Space law, thus we shall use the hypothetical case that was presented in the 2015 Manfred Lachs Space Law Moot Competition Compromis to look at how fault liability and absolute liability will work in practice. This fact complex considers two space faring nations, the United Republic of Adventura (URA) and the Sovereign Peoples Independent Democratic Republic (SPIDR) who both launch space craft to the same celestial body, and one of whose space craft then takes action against a near-Earth object which results in damage to the other state. The following hypothetical situation is described:

Within three days FUSA [Federal URA Space Agency] decided to station the spacecraft ahead of the asteroid to speed it up in order to ensure that the asteroid would miss the 2028 keyhole. Within three

\footnotetext{
Massie Second year LLB, University of Pretoria; Morris Second year BA Law, University of Pretoria.

1 The Statute of the International Court of Justice, art 38 (1)

2 Vienna Convention on the Law of Treaties (23 May 1969) UN Doc a/Conf.39/27 / 1155 UNTS 331 / 8 ILM 679 (1969) 63 AJIL 875 (hereinafter Vienna Convention) art 18(a).
} 
more days, FUSA announced that TYRUS [an unmanned spacecraft] had been able to move itself into a relatively stationary position ahead of the asteroid, and that the process of gravity tractoring to gradually speed it up had been successfully initiated.

Following the announcement of the decision on 22 August 2024 to speed up Syd-1, the SPIDR Space Agency quickly calculated that the effects of the TYRUS mission on the asteroid would amount to virtually dragging the potential impact point across the surface of, inter alia, SPIDR before it would disappear off the Earth altogether. This also meant, according to the SPIDR Space Agency, that if something went wrong in the course of TYRUS' operations, the chances of Syd-1 actually crashing into SPIDR territory would be considerably larger. (...)

URA launched TYRUS from Floyd-4 and knocked KNUD-1 [an unmanned space craft belonging to SPIDR] over in the launch process. This resulted in the loss of communication between SPIDR and KNUD1. As such KNUD-1 was unable to fulfil its purpose of sending information to the SPIDR agency regarding any developments on the Floyd-4. In addition, SPIDR lost control of the space craft. ${ }^{3}$

There are therefore two main questions that will be discussed in this article: whether a state can be held absolutely liable for its actions if it, in changing the course of an asteroid affect the area of damage and whether a state can be held liable on the basis of fault for damage caused by its space craft to another space craft if the damage was anticipated and the second state was warned not to be in that specific location.

\section{The absolute liability of a state with regards to damage caused by a near-earth object which they have affected}

Article 7 of the Outer Space Treaty states that the launching State of any space object is internationally liable to the victim State for damage caused by its space object to the other State party. ${ }^{4}$ Article 2 of the Liability Convention provides that the launching State shall be held absolutely liable to pay compensation for damage caused by

32015 Manfred Lachs Space Law Moot Court Competition Compromis para 19, 20, 6 \& 8.

4 Treaty on Principles Governing the Activities of States in the Exploration and Use of Outer Space, Including the Moon and Other Celestial Bodies, entered into force 10 October 1967, art 6, 18 UST 2410, 610 UNTS 205 (hereinafter Outer Space Treaty) art 7. 
its space object on the surface of the Earth or to an aircraft in flight. ${ }^{5}$ It is by scholarship that in order to prove liability under Article 2 of the Liability Convention, three elements must be established. Firstly, damage must be shown. Secondly, this must be because of a space object. Finally, the damage must be shown to have been caused by the space object. ${ }^{6}$ Furthermore he states that as absolute liability is present in Article 2, no negligence needs to be shown. ${ }^{7}$

It is further stated that this absolute liability is essential for cases involving outer space because of the high risk posed by outer space activities, and because it protects the interests of non-spacefaring States which may suffer damage. ${ }^{8}$ Although it is stated in Article 6 of the Liability Convention that the launching State may be exonerated from this absolute liability when it is established that there is negligence or an act or omission made by the claimant state which places the claimant state at fault ${ }^{9}$ this principle may not be relevant if no negligence or act has been shown to have caused the damage on the victim state's part. Thus, absolute liability and the three elements discussed by Gorove are will be discussed.

\subsection{The possibility of a broad interpretation of absolute liability}

When interpreting treaties, the Vienna Convention can be used. Article 31 of the Vienna Convention outlines the general rules of interpretation and states: ${ }^{10}$

A treaty shall be interpreted in good faith in accordance with the ordinary meaning to be given to the terms of the treaty in their context and in the light of its object and purpose.

According to Article 32 of the Vienna Convention, supplementary means of interpretation may be used if interpretation using Article 31 '(a) Leaves the meaning ambiguous or obscure; or (b) Leads to a result which is manifestly absurd or unreasonable'. ${ }^{11}$ In this instance, as it may be argued that the exact meaning with regards to who is liable in this hypothetical case, supplementary means may be used.

5 The Convention on International Liability for Damage Caused by Space Objects, United Nations, Treaty Series, vol 961, No 13810 (hereinafter Liability Convention), art 2.

6 S Gorové 'Cosmos 954: Issues of law and Policy' (Fall 1978) 6 Journal of Space Law 139.

7 Gorové (n 6 above) 139.

8 L J Smith and A Kerrest 'Article II (Absolute Liability) LIAB', in S Hobe, B SchmidtTedd \& K Schrogl (eds) Il Cologne Commentary On Space Law (2013) 118.

9 The Liability Convention ( 5 above) art 6. This may also be linked to Article 2 of the Articles on State Responsibility.

10 The Vienna Convention (n 2 above) art 31.

11 The Vienna Convention (n 2 above) art 32. 
Article 2 of the Liability Convention states that a State shall be held absolutely liable for damage caused by its space object either on the ground or to an object in flight. ${ }^{12}$ Literature states that, in this sense, absolute liability is taken to mean liability without the need to prove fault or negligence. ${ }^{13}$ It is important to consider the great threat that could be posed by an asteroid. According to information from the NEO Shield Project, an asteroid of that size colliding with the Earth would release energy equivalent to about 80 megatons of TNT and create a crater approximately 2 kilometres in diameter. The energy released would be similar to that released in the largest $\mathrm{H}$ bomb detonation. ${ }^{14}$ The largest nuclear bomb ever detonated, the Tsar Bomba, occurred on the 30 October 1961 and created a ring of absolute destruction for 35 kilometres around the blast site. ${ }^{15}$ This should be expanded to the extent that in cases such as this where the launching State acts in order to prevent future harm, they are not held liable for the damage that results if the attempt is not completely successful.

The hypothetical situation of a future impact of a NEO with the Earth is discussed in literature. The possible actions that could be taken are discussed, and this includes the gravity tractoring method employed by FUSA. It is stated that should a NEO pose a threat to the Earth, states may be deterred from acting to address the threat by attempting to change the course of the asteroid because of the liability they would then incur should the attempt not be completely successful and the asteroid still collide with the Earth. ${ }^{16}$ The problem in this situation is that the presence of the absolute liability may then prevent the mitigation of damage for fear of being held liable for such damage. Scholarship suggest that in order to solve this, the definition of absolute liability in the Liability Convention and the Outer Space Treaty needs to be expanded so that States which act in good faith in order to mitigate the damage caused by a NEO cannot then be held liable for the damage caused by the collision of the asteroid they attempted to deflect. ${ }^{17}$

Absolute liability, specifically with regards to space law, is discussed by scholarship. It is stated that as a principle it was initially applied in international law with regards to nuclear energy in order to impose liability on a third party, regardless of the length of the chain

12 The Liability Convention (n 5 above) art 2.

13 Gorové (n 6 above) 137.

14 Neoshield 'The Threat from Near-Earth Objects', http://www.neoshield.net/en/ near-earth-objects/the-threat-from-near-earth-objects.htm (accessed March 2015)

15 CTBTO Preparatory Commission ' 30 October 1961 - The Tsar Bomba' http:// www.cbto.org/specials/testing-times/30-october-1961-the-tsar-bomba/ (accessed March 2015).

16 M Bucknam \& R Gold 'Asteroid Threat? The Problem of Planetary Defence' (2008) 50 Survival: Global Politics and Strategy 141.

17 Bucknam and Gold (n 16 above) 141. 
of causation or intervening factors. ${ }^{18}$ Literature further states that defendant's liability is not exonerated, as it usually is, by 'tortious acts, force majeure, acts of God or intervening acts of third persons' or even by an act of causation in part by the plaintiff. ${ }^{19}$ In making recommendations for space law, it is stated that absolute liability should be applied but that it should have certain maximums set for different areas of space law; the author specifically states that uses of space for peaceful activities, such as scientific research and communication, should have a low maximum liability amount. ${ }^{20}$ This further supports the idea that absolute liability, as outlined in Article 2 of the Liability Convention should be extended.

\subsection{The damage}

Scholarship states that damage under Article 7 of the Outer Space Treaty includes both material and immaterial damage. ${ }^{21}$ Article 1 (a) of the Liability Convention defines damage as including the loss of life and the loss of or damage to property of a State or person. ${ }^{22}$ The general international principle of damage as loss, either by physical injury or consequences of this injury, can also be applied. It is also stated that a claim may be made for both damnum emergens (loss suffered) and lucrum cessan (gain or profit loss). ${ }^{23}$ An exhaustive list of the possible types of damage incurred would have been impossible to achieve in the Liability Convention, so the basic definition is used along with the understanding that reparation must, as far as possible, remove all consequences of a wrongful and damaging act. ${ }^{24}$ In the event of an asteroid collision with Earth, the expected damage may include the destruction of property and the loss of lives; thus there is no argument that damage has not occurred.

\subsection{The space object}

A space object is defined in Article 1 of the Liability Convention as including component parts of a space object as well as its launch vehicle and parts thereof. It is further stated that within the Liability Convention, a space object may be defined as any man-made object originating from the Earth which is designed for use in outer space. ${ }^{25}$ The space object in this case is therefore the space craft used to alter

18 L Goldie 'Liability for damage and international law' (1965) 14 The International and Comparative Law Quarterly 1216.

19 Goldie (n 18 above) 1217.

20 Goldie (n 18 above) 1218

21 L J Smith \& A Kerrest 'Article VII' in S Hobe, B Schmidt-Tedd \& K Schrogl (eds) I Cologne Commentary On Space Law (2009) 141.

22 The Liability Convention (n 5 above) art 1 (a).

23 Smith \& Kerrest (n 21 above) 141.

24 Smith \& Kerrest (n 21 above) 105.

25 Gorové (n 6 above) 141. 
the course of the asteroid, yet the damage may directly be caused by the near-Earth object. When using these definitions, it could be argued that the asteroid, which directly caused the damage, does not qualify as a space object. In Article 2 of the Liability Convention it states that a launching State shall be absolutely liable to pay compensation for damage caused by its space object on the surface of the Earth or to aircraft in flight. ${ }^{26}$ A launching State is defined by the Liability Convention as both the State which launches or procures the launching of a space object and the State from whose territory or facility the space object is launched. ${ }^{27}$ Nevertheless, liability can be attributed to the launching state on the basis of proximate causation.

\subsection{Whether the space object caused the damage}

The victim state may argue that by implementing gravity tractoring and speeding up the asteroid the space object the space craft of the acting state caused the damage to the town and thus the acting state is liable. The damage may be caused as the change in orbit caused a change in the impact area, and caused the damage to occur to a specific location as opposed to another area of the Earth. In order for a space object to be deemed to have caused the damage, proximate causation needs to exist between the damage and the activity from which the damage resulted. ${ }^{28}$ This occurs when there is a direct link between the act and the damage, as opposed to consequential damage. Literature defines consequential damage as that which occurs from the consequences of an act and does not flow directly and immediately from the act itself. ${ }^{29}$ Although proximate causation is a principle of general international law, Article 3 of the Outer Space Treaty allows for the use of international law where areas of space law are lacking. It is further explained that this principle in applicable in determining liability in space law. Gravity tractoring may be used to change in the asteroid's course and the subsequent damage area of collision. The natural sequence of events occurs when there is an unbroken chain of events that can be established between the action and the damage. This is elaborated on by authors who state that in order for the damage to have been caused by the object, an unbroken causal chain needs to be established. ${ }^{30}$ Natural sequence may be present as the change in course, and change in likely impact zone, can be directly linked to the change in the orbit of the asteroid by the space object. This shows that proximate causation may exist between the actions of the acting state's space agency and the damage, and thus liability can be proven.

26 The Liability Convention (n 5 above) art 2.

27 The Liability Convention (n 5 above) art 1 (c).

8 Gorové (n 6 above) 141.

29 Gorové (n 6 above) 141.

30 Smith and Kerrest (n 21 above) 126. 
The test for proximate causation, as it is applied in international liability law, as consisting of two elements. Firstly, it must be shown that there is a natural sequence of events between the act and the damage. Secondly, a degree of foreseeability must exist, shown in the amount of precaution a State took. ${ }^{31}$ Foreseeability is not applicable in this instance because the Liability Convention applies absolute liability in Article 2 and therefore only natural sequence needs to be established in order to prove liability. If the result could have been foreseen and guarded against, it is considered as a natural consequence of the act. ${ }^{32}$ It is also established by scholarship that the damage defined in the Outer Space Treaty and expanded on in the Liability Convention is not limited to local and immediate damage, and may be the result of a chain of events stemming from the action of the space object. ${ }^{33}$ The change in course of the asteroid may lead to placing a specific area at a greater risk as the centre of the uncertainty ellipse was moved towards them. The change in impact area is therefore a natural consequence of the change in course of the asteroid that could have been foreseen before the action was taken.

It is further stated that damage may be extended to include instances where physical contact has not been made between the space object and the object of damage, for example in the case of electronic or laser interference. Literature expands further on damage by stating that indirect or consequential damage should also be included in claims covered by the Liability Convention. ${ }^{34}$ This shows how, even though the space object did not cause the damage by physical contact with the asteroid or the Earth, its actions can still be included as the causation of damage. In addition, it is stated that in the drafting of the liability convention no distinction was made between direct and indirect damages in regards to damage claims, and that thus both are covered in terms of the convention. ${ }^{35}$ Direct damage is outlined as that directly or immediately from, and as the probable natural consequence of, the act of the space object. Indirect damage is defined as tortious harm which flows naturally, but not directly, from the wrongful act. ${ }^{36}$ It is further shown how something classified as consequential damage can be used to claim

31 L Castellanos-Jankiewicz 'Causation and international state responsibility' (2012) Amsterdam Center for International Law Research, paper no 2012-07 Research Project on Shared Responsibility in International Law 52.

$32 \mathrm{~F} \mathrm{H}$ Bohlen 'The probable or the natural consequence as the test for liability in negligence' (1901) 49 American Law Register 85.

33 Smith and Kerrest (n 21 above) 141.

34 F von der Dunk 'International space law' in F von der Dunk \& F Tronchetti (eds) Handbook of Space Law (2015) 85.

35 C Christol 'International liability for damage caused by space objects' (1980) 74 The American Journal of International Law 361.

36 Christol (n 35 above) 360. 
compensation, as is the case with the clean-up costs of the Cosmos 954 incident. ${ }^{37}$ The damage caused by the asteroid collision, while it may be indirect, can still be traced back to the actions of the acting state and its space object, and it was thus still caused by such actions.

Scholarship states that in order to place a claim of liability, four elements should be proven: that damage was suffered, that the damage was caused by a space object, that the instrumentality was a space object and that the launching State launched the space object. The key issue here is that of instrumentality; this shows that it is not enough for a space object's action to lead to consequential damage, but that the space object itself needs to be the instrument of causing damage. ${ }^{38}$ Scholarship makes the distinction between two possible situations: the space object may be an instrument of the actual damage, or the instrument of an action which eventually resulted in action. Consequential damage is defined as that which occurs from the consequences of an act and does not flow directly and immediately from the act itself. ${ }^{39}$ If instrumentality of the space object is not proved, a claim cannot be made. This supports the view that direct cause of damage by the space object is essential in order to establish liability of the launching state.

\subsection{Whether the launching state alone would be held liable if more than one state is involved}

Article 2 of the Liability Convention states that the launching state of a space object shall be held absolutely liable for damage caused by that space object on the surface of the Earth or to an aircraft in flight. ${ }^{40}$ Article 1 of the Liability Convention defines a launching state as a State which launches or procures the launching of a space object or a State from whose facilities or territory a space object is launched. ${ }^{41}$ Authors argue that a State which procures the launching of a space object is one which places an order for the launch of a space object. ${ }^{42}$ The launching state cannot be exempt from liability based on the joint launching of the space object by them and the fellow states of any consortium or group involved in the launching of the space object. Article 5 of the Liability Convention states that when two or more States jointly launch a space object, they are jointly and severally liable. ${ }^{43}$ Furthermore, a State which sustained

37 Christol (n 35 above) 362.

38 L P Wilkins 'Substantive bases for recovery for injuries sustained by private individuals as a result of fallen space objects' (1978) 6 Journal of Space Law 161. 39 Gorové (n 6 above) 137.

40 The Liability Convention (n 5 above), art 2.

41 The Liability Convention (n 5 above), art 1.

42 LJ Smith and A Kerrest 'Article I (Definitions) LIAB' in S Hobe, B Schmidt-Tedd \& $\mathrm{K}$ Schrogl (eds) II Cologne Commentary On Space Law (2013) 107.

43 The Liability Convention (n 5 above) art 5. 
damage is permitted to claim the whole amount of compensation from one of the liable States. This State would then, if joint liability is present, be allowed to claim reimbursement from the other liable States for the amounts they are liable for. ${ }^{44}$ This means that if joint launching is shown, the victim state may still hold the launching state liable for the damage and claim compensation.

\subsection{Whether the situation changes if the launching state failed to consider the interests of other states and violated its obligation to prevent damage}

\subsubsection{The obligation to maintain peace and security}

Article 3 of the Outer Space Treaty provides that in their exploration and use of outer space State parties to the treaty should do so in the interest of maintaining international peace and security and promoting international cooperation and understanding. ${ }^{45}$ Literature states that a binding obligation is imposed by this article on States to uphold it. ${ }^{46}$ The obligation to maintain international peace and security extends to ensuring that a State's actions in the exploration and use of outer space do not jeopardise international peace and security. ${ }^{47}$ Peace and security is stated by scholarship to have the same meaning in this context as it does in the United Nations Charter, ${ }^{48}$ which includes taking 'effective collective measures for the prevention and removal of threats to the peace'. ${ }^{49}$

Furthermore, it is stated in the UN Resolution on International Cooperation in the Peaceful Use of Outer Space that the term 'peaceful purposes' that the definition had expanded to including the broader perspective of space security rather than simply the need to prevent military action. ${ }^{50}$ This is in line with the definition given by the Human Development Report which established human security as freedom from want or fear. ${ }^{51}$ This is discussed particularly in relation to natural disaster and threats. According to the report, human security consists of two main aspects: security from chronic threats and security from sudden and harmful disruptions. It can be lost over

4 As above.

45 The Outer Space Treaty (n 4 above) art 3.

46 O Ribbelink 'Article III' in S Hobe, B Schmidt-Tedd \& K Schrogl (eds) I Cologne Commentary On Space Law (2009) 66.

47 Ribbelink (n 46 above) 67.

48 As above.

49 UN Charter, art 1, para 1

50 GA Res 69/85, UN GAOR, 69th Sess, at 4, UN Doc A/RES/69/85 (2014).

51 M Futamura, C Hobson \& N Turner ‘Natural Disasters and Human Security’ (2011) United Nations University, http://unu.edu/publications/articles/natural-disasters -and-human-security.html (accessed March 2015). 
a long period of time or in a sudden event and may be caused by man's actions, natural forces or a combination of the two. ${ }^{52}$

Environmental security, as an element of human security, is particularly relevant in this matter as the security of the people of the affected area was compromised by the environmental event of the asteroid, which occurred there due to the launching state's actions. Other forms of natural events that have been discussed under environmental security are earthquakes and tsunamis. ${ }^{53}$ Human security is established as an international law concept by the report. It is inherent that human security be used in this case as the threat to the victim state was not one of military action but of a natural event altered so that they were placed at risk.

Furthermore, it is stated in Article 9 of the Outer Space Treaty that State parties to the Treaty should be guided by the principle of cooperation and mutual assistance and should conduct all activities in space with due regard to the corresponding interests of all other states. ${ }^{54}$ Literature states that the principle of cooperation as outlined in Article 9 should not be misinterpreted as an actual obligation on the part of parties to the treaty, but rather as a general guiding principle. ${ }^{55}$ Scholarship further states that the principle of due regard serves to limit the freedom of State's actions in outer space by requiring them to ensure that their actions do not interfere with or compromise the safety of other space operations. The state should prove beyond reasonable doubt that everything possible was done to prevent a harmful action from occurring. These articles show that in their activities in outer space, States should keep the interests of all States in mind. It is stated that this extends to ensuring nonspace-faring countries and States still benefit, to some degree, from the results and benefits gained from space activities. ${ }^{56}$ This is upheld by the Declaration of Legal Principles Governing the Activities of States in the Exploration and Use of Outer Space which states that in their exploration and use of outer space states should ensure their actions are to the benefit and in the interest of all mankind. ${ }^{57}$ It is clear from an examination of these provisions that they do not in fact place any obligation on State parties to the treaties to directly protect other States from damage or harm. The United Nations Draft Report on the UN Inter-Agency Meeting on Outer Space Activities,

52 United Nations Development Programme, Human Development Report 1994, 23 (1972).

53 Futamura, Hobson \& Turner (n 51 above).

55 S Marchisio 'Article IX' in S Hobe, B Schmidt-Tedd \& K Schrogl (eds) I Cologne Commentary On Space Law (2009) 174

56 Marchisio (n 55 above) 174.

57 Declaration of Legal Principles Governing the Activities of States in the Exploration and Use of Outer Space, 13 Dec, 1976, adopted by the General Assembly in Resolution 1962 (XVIII). 
however, uses the term when discussing how satellite geographic imaging systems (GIS) can be used in the detection and management of natural disasters, such as earthquakes. ${ }^{58}$ As such, it may be argued that the obligation to ensure peace and security extends to protecting the general security of other states, and not simply abstaining from acting against them.

\subsubsection{Whether the launching state's action amount to unlawful use of its territory to cause the victim state harm if consultation did not occur}

Scholarship explains that a duty exists in international law for states to 'avoid causing damage to other states and to natural person'. ${ }^{59}$ Furthermore in the Corfu Channel case it was asserted that every state has an obligation to not knowingly allow its territory to be used for acts contrary to the rights of other states. ${ }^{60}$

Literature discusses the possible future implications that a NEO collision such as that of discussed in this hypothetical situation could have. It states that in such instances, if amendments were not made to the Outer Space Treaty and Liability, governments involved in deflecting a NEO would be held responsible. ${ }^{61}$ Scholarship states that States, in that case, may attempt to reduce damage caused by deflecting the asteroid to another area that would result in less damage, specifically to the State itself. Should a state act to protect their own interests rather than those of the world this could directly go against the principles of the Outer Space Treaty and the UN Charter, which stipulates that one of the purposes of the United Nations is to maintain international peace and security. ${ }^{62}$

Article 9 of the Outer Space Treaty states that if a State has reason to believe that their actions may potentially interfere harmfully with the activities of another State it should undertake consultations with such a State before taking such action. ${ }^{63}$ Furthermore, it is stated that if a State is aware of the potential risk that another State's activities may pose to them, they may request consultation. ${ }^{64}$ There may occur instances when the launching state may inform the victim states or the world in general of their

Draft Report on the Peaceful Uses of Outer Space, UN SGOR, 30th Sess, Supp \#, Geneva, 10-12 March 2010 Agenda Item 3(b) Report of the Secretary-General on the coordination of space-related activities within the United Nations system: directions and anticipated results for the period 2010-2011.

59 Christol (n 35 above) 353.

60 Corfu Channel (UK v Albania) (Merits) 1949 ICJ 4 (Apr 9) reprinted in 43 AJIL 558, 4 and 22.

61 Bucknam and Gold (n 16 above) 152.

62 UN Charter art 1 para 1.

63 The Outer Space Treaty ( 4 above) art 9.

64 The Outer Space Treaty ( 4 above) art 9 . 
intentions to take action against an asteroid without disclosing the full effect or consequences thereof. Scholarship states that States have an obligation to consult with other States that may be negatively affected by their actions before they undertake such an action. ${ }^{65}$ Literature further states that in terms of Article 9 the protection of the outer space extends to include the safety of outer space and the terrestrial environment. ${ }^{66}$ The consultation necessary by the State implementing the action needs to occur before the action is authorised, while the State to be affected may request consultation at any stage, even once the action has been implemented. ${ }^{67}$

A recommendation as to the consultation that is necessary is outlined in the Draft Code of Conduct for Outer Space Activities. ${ }^{68}$ This states that States should inform other States that may be at risk because of their actions in a timely manner and to the greatest extent that it is feasible of the risk posed by the actions. ${ }^{69}$

\subsubsection{The application of reciprocity and liability}

It is stated in Article 3 of the Outer Space Treaty that actions should be in line with international law. ${ }^{70}$ Under this, interpretations of liability can be used from international law. Richard Epstein discusses a form of causation and the obligation to prevent harm under the concept of strict liability that deal with reciprocity. The basis of this is that in preventing doing harm to another person, the first person suffers harm as a result. ${ }^{71}$ This is particularly apparent in this case as the launching state acted to prevent future possible harm. Had they not been allowed to act, or had they been made to change their course of action to slow down the asteroid, they may have placed themselves at risk of damage similar to that incurred by the victim state. The launching state has no direct obligation to protect the victim state from harm, and thus their actions may have been taken in order to allow for the least amount of harm. Scholarship further expands on causation by listing four general types, the final of which is causation and dangerous conditions. A dangerous condition occurs in one of three ways. First, an object may dangerous in itself, such as an explosive. Secondly, the object may be placed in a position that makes it dangerous, either by inhibiting right of way or in a position that it may cause damage. Finally the object may be dangerous because it is defective, for example a chair manufactured incorrectly.

65 Marchisio (n 55above) 179.

66 Marchisio (n 55 above) 176.

67 Marchisio (n 55 above) 180

68 Marchisio (n 55 above) 181.

69 Council Conclusions of 27 September 2010 on the revised draft Code of Conduct for Outer Space Activities, UN General Secretariat, UN Doc 14455/10, 9.

70 The Liability Convention (n 5 above), art 3.

71 R Epstein 'Theory of Strict Liability' (1973) The Journal of Legal Studies 164. 
This becomes important because causality and liability can only be established if the condition created by defendant is seen to be one of these three, and is not a 'mere condition'. ${ }^{72}$

\section{Fault liability of a state for damage caused in outer space}

Article 3 of the Liability Convention provides that a launching State is liable for damage caused by its space object to another space object in outer space, if the launching State is at fault. ${ }^{73}$ From this provision it becomes clear that a claiming state must then prove that firstly there is damage which they suffered and then lastly that the launching state was at fault in causing the damage. Continuing with our hypothetical case of two space faring nations.

URA launched TYRUS [an unmanned spacecraft] from Floyd-4 and knocked KNUD-1 [an unmanned space craft belonging to SPIDR] over in the launch process. This resulted in the loss of communication between SPIDR and KNUD-1. As such KNUD-1 was unable to fulfil its purpose of sending information to the SPIDR agency regarding any developments on the Floyd-4. In addition, SPIDR lost control of the space craft. ${ }^{74}$

\subsection{Damage in question fall within scope of the Liability Convention}

The first thing that must be established is that damage has been suffered by the claimant state in terms of the Liability convention. Article 1 (d) of the Liability Convention defines damage to mean:

loss of life, personal injury or other impairment of health; or loss of or damage to property of states or of persons, natural or juridical, or property of international intergovernmental organizations. ${ }^{75}$

In our hypothetical case above the harm suffered by SPIDR, the claimant, is loss of communication. From a positivistic reading of this provision, it could be argued that communication does not form part of damage and thus the harm suffered is not covered within the liability convention. This is looking at the fact that communication is not included in the enumerated list. Furthermore article 31(4) of the Vienna Convention on treaty interpretation says we give words special meaning if the parties to the treaty so indented. ${ }^{76}$ However the liability convention does not define what is meant by physical

72 Epstein (n 71 above) 179

The Liability Convention ( 5 above) art. 3.

Manfred Lachs Compromise (n 3 above) 19, 6 \& 8.

The Liability Convention (n 5 above) art. 1(d).

76 Vienna Convention on the Law of Treaties (23 May 1969) UN Doc A/Conf.39/27 1155 UNTS 3318 ILM 679 (1969) 63 AJIL 875 (hereinafter Vienna Convention) art 18(a). 
damage, in the convention. However Article 12 of the Liability Convention, which provides that compensation for damage must be in accordance with international law and the principles of justice and equity. ${ }^{77}$ In the Chorzow Factory case, the Permanent Court of International Justice (PCIJ) held that 'the function of the international law of tort is to restore an injured person to the condition that would have existed had the harm not been experienced'. ${ }^{78}$ In our hypothetical case KNUD-1's mission was to collect data regarding the NEO Floyd- 4 and send this data back to the SPIDR agency in order to assist the agency in ascertaining the risks involved in attaching a larger space craft to the asteroid. ${ }^{79}$ According to Scholarship the destruction of property that renders the property unfit for the use which was intended constitutes a form of physical damage. ${ }^{80}$ Scholarship supports this view in that 'any direct interference that destroys the normal use of property also appears to fall under this definition' ${ }^{81}$ Therefore the ability to send and receive information was intrinsic to the purpose of the KNUD-1 spacecraft. When TYRUS knocked over the KNUD-1 all communication with the spacecraft was lost. ${ }^{82}$ As URA's actions damaged KNUD-1's ability to transmit data, the loss of communication rendered the KNUD-1 unfit for its purpose - therefore falling within the scope the Liability Convention.

\subsection{Proving fault}

The next and most important aspect to be proven is that the offending state is indeed at fault. Article 3 of the Liability convention provides for fault liability and not strict liability which is the general form of liability in International law. ${ }^{83}$ The difference is that fault liability requires the accused state to have acted either with malicious intent (dolus) or negligence (culpa). ${ }^{84}$ From the current sets of facts there is no indication of dolus, thus we will deal with proving negligence. According to scholarship 'fault denotes the failure to adhere to, or breach of, an obligation imposed by law' ${ }^{85}$ As such in order for URA to be liable the must be an obligation imposed by law and URA must have failed to adhere to the obligation. In other words the must be an objective minimum standard of care, to which the launching state failed to adhere to. In the case of Space law the minimum standard is

77 The Liability Convention (n 5 above) art 12.

78 Factory at Chorzow (Germ V Pol), 1927 PCIJ (ser A) No 9 (July 26)

79 The Chorzow Catory case (n 78 above).

80 C Christol The Modern International Law of Outer Space (1982) 94.

81 The Liability Convention (n 5 above) art. 1(a).

82 Manfred Lachs Compromise (n 3 above) 19

83 L J Smith \& A Kerrest 'Article III: LIAB' in S Hobe, B Schmidt-Tedd \& K Schrogl (eds) II Cologne Commentary on Space Law (2009) 132.

84 Smith \& Kerrest (n 83 above) 133.

85 As above. 
defined in Article 9 of the Outer Space Treaty, under the principle of due regard. ${ }^{86}$ There is literature which argues that 'due regard refers to the performance of an act with a certain standard of care, attention of observance' ${ }^{87}$ The general standard of care as practiced in general international law is due diligence.

In our case URA would be found negligent if it was reasonably foreseeable that the harm suffered by the KNUD-1 would occur. This is because we are dealing with fault liability and the one element of fault is negligence. Thus it is at this point that we ask was it reasonably foreseeable that the prelaunch of TYRUS, URA's Space object, would cause harm to the KNUD-1? According to scholarship 'If a State has not or could not reasonably have been aware of a potential harm of an activity or, if it did not know and could not reasonable has known it cannot be obligated to regulate such activities' ${ }^{88}$ The question of foreseeability is a factual one and must be determined on case by case bases.

Thus in our hypothetical, the claimant State would have to show that it was reasonable foreseeable that the relaunch of TYRUS would cause harmful interference with their Space craft KNUD-1. Factors such as the general volatility of outer space environment, coupled together with the close proximity of the TYRUS to the KNUD-1 on the asteroid would help to show that it was reasonably possible to foresee harm occurring from such a relaunch. Thus triggering another obligation of URA that of consultation before the relaunch. ${ }^{89}$ Thus their failure to consult or at the very least alert SPIDR of the relaunch. Adds to the launching State's culpability, as it speaks to the requirement that the Launching state must have taken the necessary measures to prevent the harm.

If the respondent state is successful in proving that the harm suffered was purely accidental and thus not foreseeable, there then can be no liability based on negligence. This is because due diligence does not require a state to prevent unforeseeable harm, that is harm which is objectively foreseeable.

\subsection{Violation of jurisdiction and control.}

Article 8 of the Outer Space Treaty provides a State with the right to maintain jurisdiction and control over its space object. ${ }^{90}$ According Scholarship jurisdiction means 'legislation and enforcement of laws

86 The Outer Space Treaty (n 4 above) art 9.

87 Marchisio (n 55 above) 175.

88 M Flemme 'Due Diligence in international law 'unpublished LLM Thesis, University of LUND, 20046.

89 The Outer Space Treaty (n 4 above) art 9.

90 The Outer Space Treaty (n 4 above) art 8. 
and rules in relation to persons and objects'. ${ }^{91}$ Control is subsequently interpreted as 'the exclusive right and the actual possibility to supervise the activities of a space object and if applicable the personnel thereof'. ${ }^{9}$

According to scholarship the control competence of a State is a factual situation which is ensured by technical means. ${ }^{93}$ Without the technical means to ensure control, a state would have no de facto control.

In the case of the KNUD-1 the technical means were communication. The ability to communicate with the KNUD-1 spacecraft enabled SPIDR agency to supervise the KNUD-1's mission on the Floyd-4. This is even more important in the case of the KNUD-1 since it was an unmanned space craft. As such when KNUD-1 lost its ability to send and receive all communication the SPIDR agency lost actual control. The Applicant would submit that this right to exercise control over KNUD-1 was lost due to the loss in communication caused by the TYRUS.

Therefore, in addition to causing damage to the KNUD-1, it interfered with SPIDR's right as a sovereign State over its own space craft. It must be noted that such an application for a violation of a state's right by another can only be brought under article 7 of the outer state treaty which provides for a launching state's international liability for damage caused by its space object. ${ }^{94}$ The liability convention does not provide for such a claim; however this does not mean there is no recourse for SPIDR. SPIDR can still rely on article 2 of the Articles on State responsibility, as the basis for this claim. The applicant would have to show that the elements of an internationally wrongful are present. That is there is an act which is attributable to the launching state and that act constitutes a breach of an international obligation of the state. ${ }^{95}$ Jurisdiction and Control feed into each, without Jurisdiction one cannot have control, and you need control over the object in order to be able to enforce your own laws on the space object. This right is afforded to the launching State, in terms of article 1(a) of Liability Convention, not necessarily the owner of the space craft. ${ }^{96}$

91 B Schmidt-Tedd \& S Mick, 'Article VIII' in S Hobe, B Schmidt-Tedd \& $\mathrm{K}$ Schrogl (eds) I Cologne Commentary on Space Law (2009) 157.

92 Schmidt-Tedd \& Mick (n 91 above).

93 S Marchisio 'National Jurisdictions For Regulation Space Activities of Governmental and Non- Governmental Entities' (2010) http://www.unoosa.org/ pdf/pres/2010/SLW2010/02-02.pdf. (accessed March 2015).

94 The Outer Space Treaty (n 4 above) art 7.

95 The international Law Commission's Articles on State Responsibility, art 2.

96 The Liability Convention (n 5 above) art $1(\mathrm{a})$. 


\subsection{Liability for loss in potential harvesting}

SPIDR attached KNUD-1 to the Floyd-4 successfully; subsequently URA announced its plan to send TYRUS to the asteroid during it next near earth pass. SPIDR warned URA of that attaching a second space craft to Floyd-4 may alter the surface area of the asteroid. URA ignored this warning and proceeded with its mission to the asteroid without any prior consultation with SPIDR. Subsequently, TYRUS altered the surface area of the asteroid when trying to attach to it. This damage caused to the asteroid severely hampered SPIDR's harvesting mission. ${ }^{97}$

\subsubsection{Appropriate measures to prevent harm}

Article 1 of the Outer Space Treaty identifies outer space as the province of mankind. ${ }^{98}$ In doing so it requires that activities in outer space be carried out for the benefit of all mankind. ${ }^{99}$ In addition, States are obligated to carry out their missions with due regard for the corresponding interest of other States. ${ }^{100}$

There is scholarship in support of the view that both the Outer Space Treaty and the Moon Agreement recognise the fragility of the moon environment and the environment of other celestial bodies, as they both obligate States to take measures to mitigate damage. ${ }^{101}$ Article 9 of the Outer Space Treaty requires a State to take appropriate measures to avoid possible harm to outer space and celestial bodies. ${ }^{102}$ Article 7(1) of the Moon Agreement further obligates State parties to the treaty to take preventative measures in order to avoid disruption of the environment of celestial bodies. ${ }^{103}$ The provisions in Articles 9 Outer Space Treaty and 7(1) of the Moon Agreement respectively recognise the need to preserve the outer space environment. According to scholarship the provisions mentioned above together with the fragility of outer space environment warrant the application of the precautionary principle to outer space as it is in line with the obligation to exercise due regard. ${ }^{104}$

The precautionary principle is applied in cases where there exist uncertainties about the dangers regarding possible harm to the

\footnotetext{
97 Manfred Lachs Compromise (n 3 above) 8, 10, 19, 22.

98 The Outer Space Treaty ( $\mathrm{n} 5$ above) art 1

99 The Outer Space Treaty (n 5 above) art 1.

100 The Outer Space Treaty (n 5 above) art. 9.

101 P Larsen 'Application of the Precautionary Principle to the Moon' (2006) 71 Journal of Air Law and Commerce 298.

102 The Outer Space Treaty (n 5 above) art 9.

103 The 1979 Agreement Governing the Activities if States on the Moon and other Celestial Bodies, art7(1). 104 Larsen (n 101 above) 298.
} 
environment. ${ }^{105}$ There is scholarship in support of the view, that the precautionary principle is the acceptance of uncertainty and the need to take the uncertainty into consideration regarding lunar activities. Indeed, in order to mitigate harm, a State must use the best scientific data available. ${ }^{106}$ Scholarship identifies two types of uncertainties: epistemic and ontological uncertainty. Epistemic uncertainty is the lack of enough data regarding possible harm that the activity in question may cause to the environment. In contrast; ontological uncertainty has to do with the nature of the environment itself. ${ }^{107}$ In the current case scientific data that pointing to the certainty of harm occurring to the asteroid Floyd-4, involving the attachment of a second space object was available. ${ }^{108}$ URA ignored SPIDR's warnings, which ultimately lead to the alteration the surface of the Floyd-4. 09 Moreover URA did not consult with SPIDR before launching TYRUS to the Floyd-4. URA's failure to consider SPIDR's warning fails to meet the minimum standard mandated by the precautionary principle. The precautionary principle specifically requires preventative action to be taken even before scientific proof of harm can be submitted. ${ }^{110}$ URA failed to take reasonable step to inform itself of factual and scientific components, ${ }^{111}$ which would have allowed the state to take appropriate measures in time. ${ }^{112}$ As such URA failed to meet the minimum standards of the precautionary principle. As the principle is intrinsically linked to the obligation to act with due regard URA failed to fulfil its duties mandated by both the Outer Space Treaty and the Moon Agreement respectively. The provisions just dealt with above deal with the protection of the Outer Space environment.

Outer space is the province of all mankind and all States have free and equal access to outer space. ${ }^{113}$ Moreover Article 3 of the Liability Convention holds a launching State is liable for damage caused by its space object in outer space. ${ }^{114}$ A State's activities in outer space must not preclude other State parties from exploring outer space.

105 R Cooney 'The precautionary Principle in Biodiversity Conservation and Natural Resource Management: An issues paper for policy makers, researchers and practitioners' IUCN (2004) 5.

106 Cooney (n 105 above) 5 .

107 As above.

108 Manfred Lachs Compromis (n URA launched TYRUS from Floyd-4 and knocked KNUD-1 [an unmanned space craft belonging to SPIDR] over in the launch process. This resulted in the loss of communication between SPIDR and KNUD-1. As such KNUD-1 was unable to fulfil its purpose of sending information to the SPIDR agency regarding any developments on the Floyd-4. In addition, SPIDR lost control of the space craft. above) 8.

109 As above

110 O Mclntyre \& T Mosedale 'The Precautionary Principle as a Norm of Customary International Law' (1997) 1 International Environmental Law 236.

111 Manfred Lachs Compromis (n URA launched TYRUS from Floyd-4 and knocked KNUD-1 [an unmanned space craft belonging to SPIDR] over in the launch process. This resulted in the loss of communication between SPIDR and KNUD-1. As such KNUD-1 was unable to fulfil its purpose of sending information to the SPIDR agency regarding any developments on the Floyd-4. In addition, SPIDR lost control of the space craft. above) 8 . 
This is why appropriation of outer space is prohibited whether it's done out right through a moratorium by any other means. ${ }^{115}$ According to scholarship damage which results directly from the act of the launching State is recoverable under the Liability Convention and that loss of profits is one such type of damage which may be recovered by a state which has suffered injury. ${ }^{116}$

He further asserts that if the causation requirement is present and if harm has been experienced, loss of profits is recoverable under the liability convention. ${ }^{117}$ Furthermore international law of tort requires that a victim be restored to the position they would have been but for the harm done. ${ }^{118}$ In this case TYRUS damaged the surface area of the Floyd-4, and which subsequently lead to KNUD-2's inability to attach properly to the surface of Floyd-4. As a result KNUD-2 could only harvest 10 percent of the planned harvest. ${ }^{119}$ Therefore an unbroken

112 Marchisio (n Furthermore, it is stated in Article 9 of the Outer Space Treaty that State parties to the Treaty should be guided by the principle of cooperation and mutual assistance and should conduct all activities in space with due regard to the corresponding interests of all other states. Literature states that the principle of cooperation as outlined in Article 9 should not be misinterpreted as an actual obligation on the part of parties to the treaty, but rather as a general guiding principle. Scholarship further states that the principle of due regard serves to limit the freedom of State's actions in outer space by requiring them to ensure that their actions do not interfere with or compromise the safety of other space operations. The state should prove beyond reasonable doubt that everything possible was done to prevent a harmful action from occurring. These articles show that in their activities in outer space, States should keep the interests of all States in mind. It is stated that this extends to ensuring non-space-faring countries and States still benefit, to some degree, from the results and benefits gained from space activities. This is upheld by the Declaration of Legal Principles Governing the Activities of States in the Exploration and Use of Outer Space which states that in their exploration and use of outer space states should ensure their actions are to the benefit and in the interest of all mankind. It is clear from an examination of these provisions that they do not in fact place any obligation on State parties to the treaties to directly protect other States from damage or harm. The United Nations Draft Report on the UN Inter-Agency Meeting on Outer Space Activities, however, uses the term when discussing how satellite geographic imaging systems (GIS) can be used in the detection and management of natural disasters, such as earthquakes. As such, it may be argued that the obligation to ensure peace and security extends to protecting the general security of other states, and not simply abstaining from acting against them. above) 180

113 The Outer Space Treaty (n Article 7 of the Outer Space Treaty states that the launching State of any space object is internationally liable to the victim State for damage caused by its space object to the other State party. Article 2 of the Liability Convention provides that the launching State shall be held absolutely liable to pay compensation for damage caused by above) art 1 .

114 The Liability Convention ( $\mathrm{n}$ its space object on the surface of the Earth or to an aircraft in flight. It is by scholarship that in order to prove liability under Article 2 of the Liability Convention, three elements must be established. Firstly, damage must be shown. Secondly, this must be because of a space object. Finally, the damage must be shown to have been caused by the space object. Furthermore he states that as absolute liability is present in Article 2, no negligence needs to be shown. above) art 3.

115 The Outer Space Treaty (n Article 7 of the Outer Space Treaty states that the launching State of any space object is internationally liable to the victim State for damage caused by its space object to the other State party. Article 2 of the Liability Convention provides that the launching State shall be held absolutely liable to pay compensation for damage caused by above) art 2 . 
chain linking the damage suffered and the space object is present. A possible defence that can be raised by the respondent state to this argument that, both the Outer Space Treaty and the Moon Agreement are silent as to the nature of the measures to be taken by a State. Article 3 of the Outer Space Treaty requires that parties conduct their activities in outer space in accordance with international law. ${ }^{120}$

Therefore Article 3 permits us to look to international law where there is a gap in space law or where the provisions of a treaty are not clear enough. A State is required to act with due diligence in the prevention of harm to the environment of celestial bodies as stipulated in Article 9 of the Outer Space Treaty. According to scholarship due diligence is not an absolute duty to prevent all harm, but a requirement for a State to take reasonably measures as to avoid harm. ${ }^{121}$ Since the precautionary principle is merely read into the provisions of Article 9 of the Outer Space treaty, compliance with due diligence would amount to the fulfilment of due regard. ${ }^{122}$ This would satisfy URA's obligation completely.

Liability for damage occurring in outer space is based on fault, thus you need either dolus or culpa on the launching state. The most important and somewhat contentious elements to a liability claim are the scope of the damage and actually establishing fault on the part of

116 Christol (n In our hypothetical case above the harm suffered by SPIDR, the claimant, is loss of communication. From a positivistic reading of this provision, it could be argued that communication does not form part of damage and thus the harm suffered is not covered within the liability convention. This is looking at the fact that communication is not included in the enumerated list. Furthermore article 31(4) of the Vienna Convention on treaty interpretation says we give words special meaning if the parties to the treaty so indented. However the liability convention does not define what is meant by physical damage, in the convention. However Article 12 of the Liability Convention, which provides that compensation for damage must be in accordance with international law and the principles of justice and equity. In the Chorzow Factory case, the Permanent Court of International Justice $(\mathrm{PCIJ})$ held that 'the function of the international law of tort is to restore an injured person to the condition that would have existed had the harm not been experienced'. In our hypothetical case KNUD-1's mission was to collect data regarding the NEO Floyd-4 and send this data back to the SPIDR agency in order to assist the agency in ascertaining the risks involved in attaching a larger space craft to the asteroid. According to Scholarship the destruction of property that renders the property unfit for the use which was intended constitutes a form of physical damage. Scholarship supports this view in that 'any direct interference that destroys the normal use of property also appears to fall under this definition'. Therefore the ability to send and receive information was intrinsic to the purpose of the KNUD-1 spacecraft. When TYRUS knocked over the KNUD-1 all communication with the spacecraft was lost. As URA's actions damaged KNUD-1's ability to transmit data, the loss of communication rendered the KNUD-1 unfit for its purpose - therefore falling within the scope the Liability Convention. above) 94 .

117 As above.

118 The Chorzow Factory Case ( 78 above).

119 Manfred Lachs Comproise (n 2 above) 12, 22

120 The Outer Space Treaty ( $\mathrm{n}$ above) art 3.

121 A Kiss \& D Shelton Guide to International Environmental Law (2007) 90.

122 See the discussion of due regard principle above. 
the launching state. Some violation of right a type of damage occurring in outer space may not be covered under the Liability Convention Jurisdiction and control being such a right as was demonstrated above. Damage such as loss in potential harvesting capability though seems to fall within the scope of the liability convention may prove somewhat difficult to prove on claimant state. This is due to their environmental nature. As it is based on the principles such as due regard, which are not hard and fast rules as to stands that must be applied.

\section{Conclusion}

Liability in space law is thus a complex issue, and while there is much discussion on the matter by academics, the fact that few cases have occurred involving liability in space means that it is still unsure exactly how these concepts and differing opinions will be applied in practical cases. While it is clear that space law does make provision for situations such as the hypothetical one discussed, more clarity is needed on certain aspects particularly given the great advances in space technology over the past few years. 